\title{
Relict Soil Evidence for Profound Quaternary Aridification of the Atacama Desert, Chile
}

\author{
Angela Ebeling ${ }^{a}$, Erik Oerter ${ }^{\mathrm{b}, \mathrm{d}}$, J.W. Valley ${ }^{\mathrm{c}}$, and Ronald Amundson ${ }^{\mathrm{b} * *}$
}

${ }^{a}$ Wisconsin Lutheran College, 8800 W Bluemound Rd, Milwaukee, WI 53226 USA; angela.ebeling@wlc.edu

${ }^{\mathrm{b}}$ Environmental Science Policy and Management, 130 Mulford Hall, University of California, Berkeley, CA 94720 USA;

'Department of Geoscience, The University of Wisconsin, Madison, WI 53706 USA.

${ }^{\mathrm{d}}$ Current address: Department of Geology and Geophysics, University of Utah, 115 S. 1460

E., Salt Lake City, UT 84112-0102, USA.

**corresponding author: earthy@berkeley.edu

\begin{abstract}
A relict soil on a late Tertiary/early Quaternary gravelly alluvial fan in the southern Atacama Desert was studied to determine if evidence of Quaternary climate change was evident in the profile. Stratigraphic relations of soil morphological features indicated that the initial phase of soil development was extensive chemical weathering with the loss of $\mathrm{Si}, \mathrm{Na}$, etc. and the formation of secondary clay. This was then followed by a prolonged period of carbonate accumulation that has discontinuously impregnated the earlier formed argillic horizons. The carbonate accumulation occurred both as fine-grained accumulations that engulfed and expanded the gravelly soil matrix, and as carbonate that formed dense and continuous coatings on gravel bottoms. Overlying the carbonate is a Holocene calcareous sand unit. Stable $\mathrm{C}$ and $\mathrm{O}$ isotope profiles of the disseminated carbonate show that this material appears to have formed under conditions of low to modest plant cover and significant soil water evaporation, very similar to soils presently found at higher latitudes and altitudes in modern Argentina. Seven transects of the carbonate laminations on the gravels at $10-\mu \mathrm{m}$ scale reveal that all show a nearly $4 \%$ increase in $\delta^{13} \mathrm{C}$ values with time over distances of approximately $150 \mathrm{~mm}$, and variable $\delta^{18} \mathrm{O}$ values. The shift in $\mathrm{C}$ isotope values, which is unlikely to be due to significant changes in $\mathrm{C} 3$ vs. C4 vegetation, reflects a profound and prolonged aridification with a corresponding lowering of plant density and soil respiration. The precise beginning of the aridification is unknown due to a lack of carbonate dating methods amenable to the time frame involved. When all changes are considered, this remarkable soil indicates that local rainfall declined from somewhere between 500 to $1000 \mathrm{~mm} \mathrm{y}^{-1}$ in the late Tertiary/early Quaternary, to the present climate of about $25 \mathrm{~mm} \mathrm{y}^{-1}$. Future work will focus on developing more precise geochronological controls, but this initial study reveals the enormous potential that carbonate-bearing relict soils have for understanding climate change.
\end{abstract}

\section{Introduction}

Paleosols play an important role in reconstructing terrestrial paleoclimate. Soils integrate climatic and vegetation conditions over extended time periods before burial $\left(10^{3}\right.$ or many more years), and are then separated from adjacent paleosols by sedimentary sequences that may accumulate over time intervals that exceed the initial exposure history of the buried

(c) 2015. This manuscript version is made available under the Elsevier user license

http://www.elsevier.com/open-access/userlicense/1.0/ 
soil. Thus, buried soils are temporally coarse records, and may not capture climatic shifts that occur on the order of $10^{4}$ or even $10^{5}$ years.

Land surfaces that are older than the Holocene all bear soils that have experienced conditions that contrast with those of today. Known as relict soils (Federoff et al., 2010), these soils have long been recognized as qualitative indicators of climatic shifts, but their utility in quantitative studies has lagged relative to buried soils. Intuitively, the most well-preserved records in relict soils should exist in landscapes that have undergone continuous aridification, since the decline in fluid flow should tend to preserve chemical and mineralogical evidence from previous intervals, and overlay on them mineral assemblages that are environmentally incompatible with those formed in earlier and more humid weathering conditions.

A region where Quaternary climate history is both poorly known and of great interest is the Atacama Desert of Chile. Estimates of the onset of hyperarid conditions range wildly, and land-based observations vary from the Oligocene (Dunai et al., 2005), to the Miocene (Alpers and Brimhall, 1988; Rech et al., 2006), to the Pliocene (Hartley and Chong, 2002; Amundson et al., 2012). Alternatively, off-shore sediments suggest Quaternary oscillations of erosion and sedimentation that generally correspond to glacial cycles (Stuut and Lamy, 2004). The on-set of aridity is of considerable tectonic interest in that the aridification of Andean Altiplano is used by some researchers as evidence of Andean uplift and rainshadow development (Garzione et al., 2008).

Here we examine a relict soil located at the present southern boundary of the Atacama Desert, where the absolute (plant-less) desert merges, over a distance of $\sim 300 \mathrm{~km}$, into a semi-arid Mediterranean climatic regime. After considering both morphological and chemical soil properties, we conclude that there has been a generally continuous, and severe, aridification of this region during the Quaternary.

\section{Materials and Methods}

\subsection{Site Selection and Information}

The site chosen for study is a deep road cut incision into what is mapped as a late Tertiary alluvial fan (Moscosco et al., 1982) by Chilean Ruta 5, the main north-south highway in Chile $\left(-28.1587^{\circ} \mathrm{S},-70.647^{\circ} \mathrm{W}\right)$. The highway incision is perpendicular to an escarpment of the fan created by a local intermittent stream called the Quebrada Algarrobal, a tributary of the Quebrada Carrizal that serves as the watershed's outlet to the Pacific (quebrada is Spanish for intermittent stream or ravine) (Fig. 1).

Geographically, the site lies in an interior depression between a low coastal set of mountains (Cordillera de la Costa) on the west, and the Andes to the east. Mortimer (1973), based on mapping at nearby Vallenar, argued that the depression largely consists of Miocene pediments and gravelly sediments, known locally as the Atacama Gravels (Fig. 2). Inset into these landforms are Pliocene and smaller assemblages of Quaternary geomorphic features (Amundson et al., 2012). Based on its relative height above the stream channel and surface features (pavement development, degree of surface clast weathering), the deposit is geochronologically consistent with other Tertiary deposits in the region (Ewing et al., 2006). Mortimer (1973) examined stream long profiles of Quebrada Carrizal, and found that both the Atacama Gravels and younger stream systems had convex long profiles. Mortimer (1973) thus 
suggested that the watershed, which receives little Andean drainage, has apparently lacked adequate water to maintain stream profile equilibrium since possibly the late Miocene.

The present climatic conditions are very arid. Long-term average conditions for the cities of Vallenar, $47 \mathrm{~km}$ to the south, and Copiapo, $93 \mathrm{~km}$ to the north, are provided in Table 1. The plant cover, at the time of sampling, was very sparse (and all plants were dead). However, the region responds to periodic intrusions of storm moisture associated with the El Nino phase of the ENSO cycle, leading to what is known as the Desierto Florido (blooming desert) (Gajardo, 1994). Among the species that respond to this moisture are Skytanthus acutus and Atriplex deserticola, Encelia canescens, Fagonia chilensis, Alona rostrata, Heliotropium myosotifolium and Heliotropium megalanthum. A number of other forbs emerge during large rainfalls. The most recent blooming event occurred in 1997-1998 (Moreira-Muñoz, 2011).

\subsection{Field and Laboratory Methods}

\subsubsection{Field}

An exposure of the upper $3+\mathrm{m}$ of the soil was cleared back to fresh soil material from the highway cut (Fig. 3a). Horizons were identified on the basis of visual and tactile properties using common pedological methods (Soil Survey Staff, 1993). Bulk samples were collected in ziplock bags and transported back to the lab, and due to the desiccated conditions, drying was not required. Gravel percentage ( $>2 \mathrm{~mm}$ particle size) was determined in the field by the sieving and weighing (using a spring-loaded scale) of coarse and fine fractions. Soil texture (and clay content) was determined in the field on the $<2 \mathrm{~mm}$ fraction using the ribbon method (Soil Survey Staff, 1993). While semi-quantitative, ribbon-based comparisons with lab analyses are within roughly $15-20 \%$ (relative) of lab-based values based on personal experience.

\subsubsection{Laboratory}

Gravels $(>2 \mathrm{~mm})$ from each horizon were separated from fines $(<2 \mathrm{~mm})$. Both the fines and the gravels were analyzed for total elemental analysis by ALS-Chemex, Reno, NV. Major element analysis was performed by lithium metaborate fusion and ICP-AES, and rare earth and trace element analyses were performed via lithium borate fusion and ICP-MS.

A subsample of the fines of each of the horizons was prepared for $\mathrm{C}$ and $\mathrm{O}$ isotope analysis of calcite by pulverizing with a mortar and pestle. Soil samples containing about 10 to 100 micrograms of carbonate were analyzed using a GV IsoPrime mass spectrometer with Dual-Inlet and MultiCarb systems. Replicates, international standards NBS18 and NBS19, and one lab standard HKC-I were measured along with samples for each run. The overall external analytical precision for multiple extractions of one sample is $\pm 0.04 \%$ (internal precision: $\pm 0.004 \%$ ) for $\delta^{13} \mathrm{C}$ and $\pm 0.07 \%$ (internal precision: $\pm 0.007 \%$ ) for $\delta^{18} \mathrm{O}$.

Four clasts from samples collected from the roadcut exposure were used for microsampling and isotopic analyses. The clasts were selected from those ejected by road construction, and thus the depth at which they were located in the soils is not known (other than that they are from within the carbonate-bearing layers). Samples were chosen in this way because a high percentage of gravels had weakly attached coatings, and the most expedient 
way to find well-attached coatings was by examining many clasts that have been exposed to the elements since road construction $(<100 \mathrm{y})$. Clasts were labeled in order of size $(1=$ smallest $(\sim 9 \mathrm{~mm}$ ), 4=largest (up to $19 \mathrm{~mm}$ in thickest segments)). Each clast was bisected with a rock saw for initial observations, and a $\sim 5 \mathrm{~mm}$ slab was then cut from one of the faces. Polished thin sections (30 microns thick) were prepared from each slab (one from each of the four clasts) and polished (see Figure 4a). For isotope analyses, small holes were drilled along transects across the carbonate rinds using a press-mounted Dremel tool and a $300 \mu \mathrm{m}$ diameter drill bit. The carbonate powder from each hole was collected and analyzed for $\mathrm{C}$ and O isotope ratios via mass spectroscopy as described above. Approximately $51 \mathrm{mg}$ of carbonate was collected from two sections of clast 4 . Section 1 was from an outer, presumably younger portion of the carbonate rind and section 2 was from an inner, presumably older portion of the carbonate rind.

In addition to the drilled transect, two clasts (\#1 and \#2) with attached carbonate rinds were selected for micro-scale ion beam sampling for $\delta^{18} \mathrm{O}$ and $\delta^{13} \mathrm{C}$ values on the carbonate rinds with the IMS 1280 Secondary Ion Mass Spectrometer (SIMS) at the WiscSIMS Laboratory, University of Wisconsin - Madison. Samples of the full-thickness carbonate rinds along with small portions of the attached clasts of approx. $4 \mathrm{~mm}$ thickness and $5 \mathrm{~mm}$ width were cut from the larger samples, cast into $\sim 25 \mathrm{~mm}$ round epoxy (Buehler EpoThin) mounts with several grains of UWC-3 (calcite standard, $\delta^{18} \mathrm{O}=-17.88 \%$ VPDB; Kozdon et al., 2009). These mounts were polished by hand on rotary disc laps with $9 \mu \mathrm{m}$ and then $3 \mu \mathrm{m}$ size alumina-water slurry. Additional rotary machine polishing was done with 3 $\mu \mathrm{m}$ and $0.25 \mu \mathrm{m}$ diamond paste in oil, followed by a final hand polish by rotary lap with colloidal silica solution $(0.05 \mu \mathrm{m})$, providing a nearly perfectly-flat low-relief polished surface. The polished samples were then sputter coated with Au to a thickness of $\sim 60 \mathrm{~nm}$.

Samples were inspected with a Hitachi S3400N scanning electron microscope at approximately 1000x magnification in secondary electron (SE) and back scattered electron (BSE) modes to identify the most suitable SIMS sampling domains according to the criteria of the most visibly pure carbonate with no inclusions or discernable laminations with no other phases present, and no cracks or voids in the sample surface. In the CAMECA IMS 1280 large radius ion microprobe multicollector instrument, a $\sim 1.7 \mathrm{nA}{ }^{133} \mathrm{Cs}^{+}$ion beam is focused into a spot size $\sim 10 \mathrm{um}$ in diameter and applied to the sample surface creating sampling pits $\sim 1$ um deep by ablating $\sim 2$ ng of carbonate (Fig. 4b,c). Precision on these samples for $\delta^{18} \mathrm{O}$ values are $\leq \pm 0.3 \%$ o (2SD), as determined by multiple analysis spots on UWC-3 standards before and after sample analyses (Kita et al., 2009). Post-SIMS analysis, samples were again imaged by SEM to evaluate SIMS pits for appropriate location, absence of cracks or inclusions revealed inside the pit and for symmetric pit shape.

\section{Results and Discussion}

\subsection{Soil Morphology}

The soil profile bears many features in common with Pleistocene soils in the Mojave Desert, Great Basin, or the Sonoran Deserts of North America (Figs. 2, 3a). Two thin horizons of relatively fresh eolian sand (nominally called A horizons, though the vegetation and organic matter accumulation was minor), with small amounts of carbonate, overlie a third 
horizon at $8 \mathrm{~cm}$ that appears to be the partially disrupted remnant of an older underlying soil (thus the use of the term " $\mathrm{b}$ " to indicate burial for all underlying horizons). Carbonate and clay (Fig. 6a, d) increase in the $4^{\text {th }}$ horizon, and carbonate reaches a maximum in the $5^{\text {th }}$ horizon (Btkmb), while clay reaches a near maximum of $36 \%$ in the $7^{\text {th }}$ horizon, and remains constant to the depth of the exposure. There is a general inverse relationship between gravel content and carbonate (Fig. 6a, d). One of the immediate features recognizable in the field (especially in horizons 6, 7, and 8) were occasional well-developed, angular blocky and somewhat reddish (7.5YR) soil structural units that were free of carbonate yet were embedded in horizons that were overall carbonate-rich (Fig. 3b). Clay formation, being a process requiring considerable water and time, is chemically incompatible with the accumulation of carbonate, so that the stratigraphic relations indicate that carbonate accumulation has occurred after the clay formed, though small segments of the soil surprisingly still remain carbonate free as a result of inhomogeneous fluid flow paths.

The overprinting of carbonate on a clay-rich soil layer (Fig. 3b) has at least semiquantitative implications about climate change during soil development. Jenny and Leonard (1934), and a more recent compilation by Retallack (2004), suggest that carbonate-free soils form in climates with $\sim 100 \mathrm{~cm}$ or more of Mean Annual Precipitation (MAP) (depending to some degree on temperature, lithology, etc.). The switch to carbonate accumulating conditions (especially one that retains so much carbonate near the surface), is indicative of a decline of MAP of at least $50 \mathrm{~cm} \mathrm{y}^{-1}$ - or much more. As we discuss in the following sections, during the carbonate accumulation phase for this soil, there was a continuous increase in aridity that occurred - a process leading to the present conditions that now border on hyperarid.

\subsection{Soil Geochemistry}

The morphology of the soil profile suggests the soil experienced a considerable period of chemical weathering and clay development, followed by a long and much drier interval of carbonate accumulation. These observations should be reflected geochemically. Elemental analyses for major elements and trace elements (including rare earths) were obtained for the < $2 \mathrm{~mm}$ (fine) fraction and for fresh fluvial material collected deeper in the alluvial fan section (from a road cut exposure down section).

Gains and losses of elements relative to parent material values (the chemistry of the unweathered sediment) are calculated using a mass balance relative to an immobile index element (e.g., Brimhall and Dietrich, 1987):

$\operatorname{tau}=\mathrm{R}_{\mathrm{s}} / \mathrm{R}_{\mathrm{p}}-1$

where $R_{s}=C_{i, s} / C_{i, s}$ and $R_{p}=C_{i, p} / C_{i, p}, C=$ concentration, $i=$ immobile element, $j=$ mobile element, $\mathrm{s}=$ soil, and $\mathrm{p}=$ parent material. The selection of an index element that is both immobile and that is homogenously distributed throughout the soil (particularly in fluvial deposits) is not a trivial decision. In addition, where eolian input is likely a major factor over time, index element selection must consider impacts of exogenous mineral sources.

In fluvial deposits, sediment not only chemically reflects the source area but bears the imprint of physical sorting and winnowing. Thus an ideal index element will be distributed 
uniformly through all minerals. Most refractory elements $(\mathrm{Ti}, \mathrm{Zr})$ are concentrated in heavy and relatively rare accessory minerals in plutonic rocks: sphene, zircon, etc. However, rare earth elements (REE) are concentrated in accessory minerals and are distributed throughout the major silicates (Gromet and Silver, 1983). Which REE may be most appropriate for index element status? First, relatively high concentrations (well above detection limits of analyses) are desirable. Second, while the REE elements share chemical behavior, some are fractioned during melt cooling by different mineral fractions. For example, $\mathrm{Yb}-$ commonly in the ppm range - was reported by Gromet and Silver (1983) to be concentrated in zircon several orders of magnitude more than other REE (up to $10 \%$ of the whole rock concentrations). In the soil examined here, $\mathrm{Yb}$ is indeed correlated with $\mathrm{Zr}$ (Fig. 5a), reflecting parent material partially derived from Tertiary granitic rocks (Moscosco et al., 1982). We have no dust flux or measurements of its geochemistry at this site. In other locations in the more arid regions of the Atacama Desert, REE concentrations of dust are similar to the fluvial sediments (all reflecting a mixed, but largely granitoid, lithological source)(Ewing et al., 2006).

Gromet and Silver (1983) found that Ce and Nd are both relatively abundant in a wide range of silicate minerals formed in plutonic environments. Additionally, they are not strongly fractionated by accessory minerals. Thus, these may theoretically be good choices for index elements. Kurtz et al. (2000) examined refractory element mobility in soils formed from basalt in Hawaii. They pointed out that pairs of index elements that are both immobile and homogeneous will show constant ratios throughout a weathering profile. Fig. 5b shows a strong correlation between $\mathrm{Ce}$ and $\mathrm{Nd}$, fulfilling this criterion - both for the fine and the gravel fractions of the horizons. In contrast, Ti vs. $\mathrm{Zr}$ (the two most common index elements in many studies) comparisons have no obvious relationship (Fig. 5c), indicating that one or both are inhomogeneously distributed or mobile. Given the low abundance of accessory minerals zircon and sphene, and their high density, it is anticipated that fluvial processes will result in significant differences in the concentration of these minerals in different sedimentary layers.

For the purpose of this research, absolute gains or losses of rock forming elements are not as essential as semi-quantitative measures. Thus, we use both Ce (arguably the best index element) and $\mathrm{Zr}$ (one used in many previous studies) as index elements (though $\mathrm{Nd}$ would provide similar results as Ce). The reference horizon chosen is the fine earth fraction $(<2 \mathrm{~mm})$ from unaltered sediments collected deep in the road cut. If the lowest sampled soil horizon was used, the trends would be largely the same, but would reflect lower losses (since the lowest soil horizons sampled is still within the zone of weathering). This range of gains and losses likely captures the maximum and minimum values, and strengthens the interpretations about weathering changes over time.

The large concentration of clay beginning in the $4^{\text {th }}$ horizon (Fig. 6a), and extending to the soil base, is indicative of considerable chemical weathering of the fines and gravels in the alluvium. Chemical weathering of feldspars is a de-silication process, and thus Si and cations such as $\mathrm{Na}$ should be released and leached during the formation of secondary phyllosilicates. The tau values for both $\mathrm{Na}$ and $\mathrm{K}$ (Fig. 6b) are nearly identical (though slightly offset for the two index elements), showing considerable losses throughout the upper $200 \mathrm{~cm}$ of the soil, with decreasing losses with increasing depth. Silicon also shows a similar pattern (Fig. 6c). The shape of the Si, K, and $\mathrm{Na}$ patterns suggest that a weathering front moved through this soil to a depth of $\sim 150 \mathrm{~cm}$, weathering away the $\mathrm{K}$ and Na-bearing silicates (e.g. White et al., 2008). 
This is indicative of both considerable water and time for this degree of chemical alteration to occur. The fact that the clay accumulation (Fig. 6a) extends below the depth of Si loss is not necessarily unexpected given that colloids are mobile, and can move downward with percolating water.

The field evidence suggests that carbonate has been overlain on the carbonate-free clays. The concentration of $\mathrm{CO}_{3}$ reaches peak values at $50 \mathrm{~cm}$ (Fig. 6d), and the low gravel content of that layer is suggestive of considerable volumetric expansion associated with the $\mathrm{CaCO}_{3}$ gains. The carbonate gains decline steadily with depth and appear to reach 0 somewhere below a depth of $214 \mathrm{~cm}$ (the base of the excavation). Chemical analyses reveal an accumulation of $\mathrm{SO}_{4}$ below the maximum carbonate content (Fig. 6e). This trend of sulfate beneath carbonate is expected based on differences in respective mineral solubility along downward migrating and evaporating solutions, and is a trend found further north near Copiapo in even more arid conditions (Ewing et al., 2006). The soil examined here differs from that of Ewing et al (2006) in that the bulk of Ca-bearing salt is in carbonate form (vs. more equitable quantities in carbonate and sulfate near Copiapo to the north).

The loss of $\mathrm{Na}, \mathrm{K}$, and $\mathrm{Si}$ over several meters indicates substantial weathering losses. The magnitude of loss is driven by both the volume of water that passes through the soil (climate) and the soil age (time for the reactions to proceed). We can place the degree of $\mathrm{Na}$ loss in the soil examined here in context with modern soils, in differing climates, that form on granitic terrain (Rasmussen et al., 2011). The comparison reveals that the degree of alteration observed here lies between that of very high rain and temperatures (Puerto Rico) where all $\mathrm{Na}$ to $6 \mathrm{~m}$ has been removed and that of Colorado (cool, with MAT $=\sim 600 \mathrm{~mm}$ ). While the degree of loss is not directly proportional to rainfall, the comparison reveals the range of climate conditions needed to cause chemical weathering to depths of $2 \mathrm{~m}$.

The mass of calcium carbonate accumulated in this soil is about $22 \mathrm{~g} \mathrm{~cm}^{2}\left(220 \mathrm{~kg} \mathrm{~m}^{-2}\right.$ $\mathrm{CaCO}_{3}$ or $88 \mathrm{~kg} \mathrm{~m}^{-2} \mathrm{Ca}$ ). How much time might this accumulation represent? $\mathrm{CaCO}_{3}$ (measured by $\mathrm{Ca}$ ) deposition rates in dust the Atacama Desert are about $0.3 \mathrm{~g} \mathrm{~m}^{-2} \mathrm{y}^{-1}$ (Ewing et al., 2006). Alternatively, based on the carbonate accumulated in the upper 2 horizons of this soil (which we assume is a relatively recent, or Holocene, occurrence), the $\mathrm{CaCO}_{3}$ "recent" deposition rate is about $0.07 \mathrm{~g} \mathrm{~m}^{-2} \mathrm{y}^{-1}$. The true $\mathrm{Ca}$ accumulation rate is unknown, and may differ from those to the north (Ewing et al., 2006) due to many reasons. Based on these input estimates, the time required to accumulate the total soil carbonate could range from 0.7 to 2.9 My. While this time-frame is uncertain, it loosely supports the notion that carbonate accumulation began near the onset of the Quaternary, a time in which Pacific Ocean circulation shifted to the present La Nina/El Nino oscillation (Wara et al., 2005), and when landforms further to the north appear to reveal a near cessation of fluvial activity (Amundson et al., 2012).

\subsection{Carbonate Isotope Composition}

The soil contains a bi-modal accumulation of carbonate: a small quantity near the surface (upper $10 \mathrm{~cm}$ ), and then a second and much larger zone that begins at $\sim 50 \mathrm{~cm}$, which increases rapidly to a maximum at $\sim 75 \mathrm{~cm}$, and declines with depth. A bi-modal carbonate profile is characteristic of a change in the depth of carbonate deposition due to increasing 
aridity (Wang et al., 1996). The depth of the uppermost layer is consistent with the very low average annual rainfall, which lies between that of Vallenar to the south $(31 \mathrm{~mm})$ and Copiapo to the north $(12 \mathrm{~mm})$.

Fig. $7 \mathrm{a}$ and $7 \mathrm{c}$ show the $\mathrm{C}$ and $\mathrm{O}$ isotope profiles of the bulk carbonate in the fine grained fraction. This carbonate most likely integrates soil conditions over $10^{5}$ to $10^{6} \mathrm{y}$ given the accumulated mass. Despite the long time interval over which the carbonate accumulated, the depth trends for both $\mathrm{C}$ and $\mathrm{O}$ form characteristic profiles produced by well-understood soil processes. These processes for $\mathrm{C}$ and $\mathrm{O}$ will be discussed sequentially.

The $\mathrm{C}$ isotopes in the lower portion of the carbonate profile (excluding the upper 2 horizons) show a smooth, exponentially declining trend with depth (Fig. 7a). The two samples from the surface horizons show a slight increase with depth, but do not follow the exponential pattern of the lower layers. The $\delta^{13} \mathrm{C}$ value of the pre-industrial atmosphere was about $-6.5 \%$. At $20{ }^{\circ} \mathrm{C}$ (Deines et al., 1974), the $\delta^{13} \mathrm{C}$ value of carbonate that would form from this atmosphere is $3.7 \%$. The $\delta^{13} \mathrm{C}$ values in the surface are close to $-2 \% 0-$ reflecting an isotopically more negative $\mathrm{CO}_{2}$ source than the atmosphere. Given the very arid conditions and nearly complete lack of leaching, the carbonate likely reflects the $\mathrm{C}$ isotope composition of its source, which would be wind blown sediment from the erosion of local calcite-rich soils.

In contrast, extrapolations of the lower carbonate $C$ isotopes to the soil surface, using an exponential relationship, projects to values of around +2 to $+3 \%$, values consistent with carbonate formed from atmospheric $\mathrm{CO}_{2}$ in the Quaternary. The exponential shape is reflective of a $\mathrm{C}$ isotope profile in equilibrium with soil $\mathrm{CO}_{2}$ produced by biological production and transported by diffusion to the atmosphere (Cerling, 1984):

$R_{S}^{13}=\frac{\left(\frac{\phi R_{p}^{13}}{D_{S}^{13}}\right)\left(L z-\frac{z^{2}}{2}\right)+C_{a t m} R_{a t m}}{\left(\frac{\phi}{D_{S}}\right)\left(L z-\frac{z^{2}}{2}\right)+C_{a t m}}$

where $\phi=$ soil respiration rate, $z=$ soil depth, $\mathrm{L}=$ depth of the profile, $\mathrm{D}^{13}$ is the diffusion coefficient $\left(\mathrm{L}^{2} \mathrm{~T}^{-1}\right)$ for ${ }^{13} \mathrm{CO}_{2}$ through soil air which is $\mathrm{D}_{\mathrm{s}} / 1.0044$, and $\mathrm{R}_{\mathrm{s}}, \mathrm{R}_{\mathrm{p}}$, and $\mathrm{R}_{\text {atm }}$ refer to the ${ }^{13} \mathrm{C} /{ }^{12} \mathrm{C}$ isotopic ratios of soil $\mathrm{CO}_{2}$, plant $\mathrm{C}$, and atmospheric $\mathrm{CO}_{2}$, respectively. Using Cerling's model and the equilibrium fractionation factor between $\mathrm{CO}_{2}$ and calcite (Deines et al., 1974), carbonate profiles were calculated for differing rates of soil respiration. A respiration rate of about $45 \mathrm{~g} \mathrm{CO}_{2} \mathrm{~m}^{-2} \mathrm{y}^{-1}$ is consistent with the observed profile (Fig. 7a). Soil respiration hinges on the abundance and activity of plants, which produce $\mathrm{C}$ for soil microbes and directly respire $\mathrm{CO}_{2}$ from their roots. In Nevada (Quade et al., 1989), respiration increases with increasing elevation, to values of $137 \mathrm{~g} \mathrm{C} \mathrm{m}^{-2} \mathrm{y}^{-1}$ at 1900 masl. The present soil respiration rate (or yearly average) for our field area is not known, but must be very low, or in some years, non-existent. If we examine respiration vs. MAP for Nevada (from Quade et al., 1989), we can tentatively suggest that the respiration for our field area (MAP $\sim 20-25 \mathrm{~mm} \mathrm{y}^{-1}$ ), may be on the order of just a few $\mathrm{g} \mathrm{C} \mathrm{m}^{-2} \mathrm{y}^{-1}$ (in wet years). This is much lower than the rate indicated by the soil $\mathrm{C}$ isotope profile, suggesting a significant decline in rainfall since that carbonate profile developed. 
The $\mathrm{C}$ isotope profile also is quite similar to soils found on the eastern side of the Andes, at the latitude of $\sim 33^{\circ} \mathrm{S}$ (east of Santiago, Chile), though $\sim 2$ per mil more positive (Peters et al., 2012)(Fig. 7b). Along this elevation transect that spans from 110 to 3200 m.a.s.l., Mean Annual Temperature (MAT) ranges from $\sim 9$ to $19{ }^{\circ} \mathrm{C}$, and MAP from 132 to $320 \mathrm{~mm}$. The similarity of the Argentine soils to the relict soil examined here suggests that the past rainfall (when carbonates were forming) was an order of magnitude (or more) greater than that of today.

The O isotope profile (Fig. 7c) is also interpreted for the lower and upper portions individually. The $\mathrm{O}$ isotope composition of pedogenic carbonate is derived from the soil water (which ultimately is related to rainfall). The $\delta^{18} \mathrm{O}$ value of rainfall increases with decreasing latitude (and decreasing rainfall). The nearest long-term rainfall (stable isotope) collection location is at La Serena, about $200 \mathrm{~km}$ to the south (GNIP, 2014). At La Serena, the average precipitation is about $-5 \%$, and the projected rainfall for our site should be only slightly more positive than this value. At equilibrium (O’Neil et al., 1969), the $\delta^{18} \mathrm{O}$ value of rainfall (on the $\mathrm{V}$-SMOW scale) in equilibrium with the carbonate is about -1 to $-2 \%$ VSMOW. While the shallowest carbonate could reflect formation from evaporatively ${ }^{18} \mathrm{O}$-enriched water from present precipitation, the $\mathrm{C}$ isotopes suggest that these carbonates largely reflect isotopic inheritance from their source environment, with little in situ alteration.

As for the lower portion of the $\mathrm{O}$ isotope profile (below $30 \mathrm{~cm}$ ), the $\delta^{18} \mathrm{O}$ values decline exponentially with soil depth, a trend consistent with evaporative enrichment (Barnes and Allison, 1988; Criss, 1999). The analysis of evaporative profiles is complex. For a soil undergoing steady state evaporation (from some lower water reservoir), the shape of the profile is driven by the evaporation rate $(\mathrm{E})$ and the water diffusivity in the liquid phase (D). As an example, for the soil water below an evaporating front, the trend in $\mathrm{R}\left({ }^{18} \mathrm{O} /{ }^{16} \mathrm{O}\right.$ in water) with depth (z) is (Criss, 1999):

$R_{z}=R_{e f}+\left(R_{r e s}-R_{e f}\right)\left[\frac{1-e^{-E\left(z-z_{e f}\right) D}}{1-e^{-E\left(L-z_{e f}\right) D}}\right]$

where $z$, ef, and res = water isotope ratios at depth $z$, the evaporating front (the transition from upper dry, vapor transport zone to the lower unsaturated zone), and the unevaporated water at depth, respectively; $\mathrm{D}=$ diffusion coefficient of water $\left(\mathrm{L}^{2} / \mathrm{T}\right) ; \mathrm{E}=$ evaporation rate $(\mathrm{L} / \mathrm{T})$, and $\mathrm{L}=$ base of soil. Hydrologists have used model like Eq. 3 to calculate rates of evaporation from isotope profiles (e.g. Allison and Barnes, 1983). While the steady state assumption is tenuous for reasons described below, using a diffusivity of $1.5 \times 10^{-9} \mathrm{~m}^{2} \mathrm{sec}^{-1}$, we calculated water (and carbonate) profiles for differing evaporation rates. The matching value (5-10 $\left.\mathrm{cm} \mathrm{y}^{-1}\right)$ is similar to rates calculated by Allison and Barnes (1983) for an evaporating lake bed in Australia.

For unsaturated arid soils like the one considered here, evaporative profiles also evolve, but are the complex products of the drying of the soil over time (processes which are variable over time and depth), and thus numerical models are required to adequately capture the combined effects of time and rates of processes (e.g. Shurbaji and Phillips, 1995). Qualitatively, the observed profile (Fig. 7c) has a degree of enrichment near the top of the most carbonate rich horizon that is similar in magnitude to soils in Argentina (Peters et al., 
2012) (compare Fig. 7c and d): about 4 per mil. However, the depth of apparent enrichment is greater $(150$ vs. $50 \mathrm{~cm}$ ). While the relative role of evaporation rate vs. duration of evaporation is not possible to de-convolve, the isotopic similarity to soils in environments presently located $700 \mathrm{~km}$ to the SSE provides a guide to the hydrological conditions that existed at the time the carbonate profile developed: conditions far more humid than today.

The drilled transects across the carbonate laminations on the gravels provide a much more temporally resolved perspective on the soil stable $\mathrm{C}$ and $\mathrm{O}$ isotope environment. As a starting point, we assumed that all the examined laminations had formed over the same time interval, and that local variations in growth environments had caused slight differences in absolute lamination thicknesses. Thus, all samples were normalized to total thickness on a scale of 0 (youngest) to 1 (outermost edge of lamination). The seven transects, on four clasts, all show the same trend: an increase in $\delta^{13} \mathrm{C}$ values from $\sim-6$ to $-2 \%$ from the oldest to the youngest laminations (Fig 8a). The value of $-6 \%$ is that of the base of the bulk carbonate profile (Fig. 7a) and is similar to soil carbonate in modern Argentina (Fig. 7b). The increase in $\delta^{13} \mathrm{C}$ values in all transects is strongly suggestive of a significant decline in plant cover and soil respiration. Adjusting soil respiration in Eq. 2 to fit the measured carbonate $\delta{ }^{13} \mathrm{C}$ requires a reduction in respiration to $\sim 30$ to $40 \mathrm{~g} \mathrm{~m}^{-2} \mathrm{y}^{-1}$, representing a profound drying and reduction of plant cover.

The overall details of the hand drilled $\mathrm{C}$ isotope transects through the carbonate laminations is confirmed by a SIMS transect through LA-1 (Fig. 8c). The 51 ion microprobe data points reveal an overall increase in the $\delta^{13} \mathrm{C}$ values of $7 \%$. However, there are periodic oscillations in $\mathrm{C}$ isotopes that suggests the climatic trends were not smooth or continuous over time, and both sharp decreases and increase in ${ }^{13} \mathrm{C}$ values of up to $4 \%$ occur multiple times within the overall trend toward more positive values.

The $\mathrm{O}$ isotope $\delta^{18} \mathrm{O}$ values sampled by hand drilling were variable, but oscillated within a seemingly restricted range in all transects: $\sim-1 \pm 1 \%$ (Fig. $8 \mathrm{~b}$ ). However, the increased spatial resolution provided by the SIMS measurements reveals up to $10 \% 0$ variability among and within the carbonate rinds, with considerable structure and repeatability in the $\mathrm{O}$ isotope values across the transects (Fig. 8b). For example, in clast 1 the $\delta^{18} \mathrm{O}$ values range from -5.4 to $5.7 \%$, and a suggestion of generally increasing $\mathrm{O}$ isotope values over time. In clast 2 the oscillations are more subdued, with values ranging from -5.8 to 1.0\%o. Given that the clasts are likely from differing soil depths, one simple interpretation is that clast 2 was formed deeper in the profile, and experienced a lesser impact of near-surface evaporation than clast 1 . To support this hypothesis, both clasts have nearly the same minimum values $(\sim-5$ $\%$ ), suggesting similarity in the source of rainfall but differences in the degree of evaporative enrichment of soil water. However, the minimum values do not always match in terms of position along the sampling transect from inner to outer, but this discrepancy may be due to the fact that distance does not linearly relate to time across the transects. Alternatively, the $\delta^{18} \mathrm{O}$ values of the rainfall might be linked with quantities of rainfall, which will simultaneously affect plant density and respiration.

The high density of the SIMS measurements allow the $\mathrm{C}$ and $\mathrm{O}$ isotope patterns in clast LA-1 to be closely compared. There is clearly a strong positive correlation between trends in $\mathrm{O}$ and $\mathrm{C}$ isotopes (Fig. 8c). The correlation can be most simply interpreted as 
suggesting that a decline in rainfall caused a decrease in plant cover/productivity (increases soil $\mathrm{C}$ isotope values) which in turn increases the soil water evaporation/transpiration ratio (which increases soil $\mathrm{O}$ isotope values). The patterns also suggest that (assuming rainfall is the driving mechanism) that changes in plant productivity tightly mirror changes in $\mathrm{O}$ isotopes. There is growing evidence that the El Nino Southern Oscillation (ENSO) system has undergone enormous change since the Pliocene, when permanent El Nino (or, "El Padre", (Ford et al., 2015)) conditions dominated the Pacific. Since then, cooling of the eastern Pacific has helped institute the ENSO cycle, which now modulates decadal patterns of moisture in the southern Atacama Desert (Houston, 2006).

Clearly, in the absence of geochronological controls, the linkage of the $\mathrm{O}$ isotope record to other isotope or climate records is impossible, but the SIMS transects do point to the enormous information and high resolution climate data stored within soil profile features, information that will be fully utilized once suitable dating techniques are developed. Given that present, and likely past, precipitation is derived from westerlies from the Pacific (Stuut and Lamy, 2004), the $\mathrm{O}$ isotope values indicate variability within this climate system and with changes in land surface features such as plant density, which control soil water evaporation.

\subsection{Paleoclimatic Significance}

Determining the multi-million year paleoclimate of the Atacama Desert with reasonable temporal resolution has been a vexing problem. As reviewed earlier, there is disagreement between various studies and approaches - all hindered to some degree by geochronological control. The soil examined here has only broad geochronological constraints: it likely began to develop sometime in the late Tertiary. The soil properties, support or supplement these age constraints. First, the thick and high-clay argillic horizons suggest not only initial humid to semi-humid conditions, but also a long duration of weathering. The starting material was gravelly alluvium, and in California, soils with sandy alluvium require $\sim 275$ to $1000 \mathrm{Ky}$ to develop similar argillic horizons (Harden, 1988). While this is not directly extrapolatable to Chile, it does provide an order of magnitude perspective on chemical weathering in semi-arid, strongly seasonal, conditions. In addition, the amount of post-argillic accumulation of carbonate seems to require long time periods to develop, which when linked with the clay formation interval, is loosely consistent with the assumed late Tertiary/early Quaternary age of the soil.

We know of no multi-million year, high resolution, continental climate records for the region. Oerter et al. (2011) found that a series of $\sim 20$ buried soils in late Oligocene/early Miocene fluvial gravels $\sim 600 \mathrm{~km}$ to the north showed transitions between clay-forming and carbonate-forming environments (no sulfates or other hyperarid salts were found). This location, near Calama at $22^{\circ} 30^{\prime} \mathrm{S}$, is at the present northern-most boundary of austral winterderived Pacific storms which affect the climate at the site of this study (Houston, 2006). In addition, just to the east of Calama are sulfate and nitrate rich buried soils that reflect longterm hyperarid conditions and are constrained to be $\sim>9.4 \mathrm{Ma}$ (Rech et al, 2006). Thus, in the north, hyperaridity first established itself $\sim 10$ My ago. Amundson et al (2012) found that $\sim 150 \mathrm{~km}$ to the south, the region showed a significant onset of hyperaridity beginning $\sim 2.2$ Ma based on: (1) regional sediment removal by streams largely ceased in the Quaternary, (2) local hill/mountainslope shed silicate soil mantles, which accumulated locally at the slope bases, $\sim 2 \mathrm{Ma}$, and (3) post $2 \mathrm{Ma}$ soil formation seems to have largely been constrained to 
hyperarid conditions based on no detectable signals of major soil poly-genesis (e.g. Ewing et al., 2006), with the exception of possible brief pluvial episodes which appear to have impacted the upper 30 to $40 \mathrm{~cm}$ of the soils.

\section{Summary and Future Research}

The soil examined here, located at the present desert/semi-arid boundary, exhibits (based on the resolution of approaches used here) relatively continuous aridification since late Tertiary times. The soil's climatic history is a progression from humid to sub-humid clay forming conditions, through a long carbonate-accumulating phase that ended with a prolonged period of declining soil respiration. Throughout this period the source (based on stable $\mathrm{O}$ isotopes) of the precipitation appeared to remain relatively constant, while the overall amounts of precipitation or soil water declined.

While the information deciphered thus far from this relict soil is remarkable, more can be determined through future research: (1) cosmogenic isotope profiles (e.g. Jungers et al., 2013) or ash exposures can be used to date the age of the alluvial deposit and more precisely determine the onset of soil formation, (2) more closely spaced micron-scale stable $\mathrm{C}$ and $\mathrm{O}$ isotope transects using Secondary Ion Mass Spectrometry (SIMS) might further identify and resolve - at $\sim 10^{3} \mathrm{y}$ time intervals - temporal variability in climate, and (3) it seems that additional radiometric dating techniques, such as $\mathrm{U}-\mathrm{Pb}$ dating which has yet to be developed for soil carbonates, must be adapted in order to accurately place the stable isotope record in a temporal framework. Are there trace elements in these carbonates? Are they useful?

While these efforts greatly exceed the goals of this exploratory research, they seem attainable with additional resources and research in geochemistry. Carbonate-bearing relict soils are a characteristic feature of deserts around the world, and it is probable that many of these landscapes bear soils that retain a strong and detailed chemical memory of the past.

\section{Acknowledgments}

WiscSIMS is partially supported by the U. S. National Science Foundation (EAR03-19230, EAR10-53466, EAR13-55590). We thank Reinhard Kozdon, Ian Orland and Kouki Kitajima for guidance and assistance in the SIMS analyses. Marco Pfieffer provided information about the floral communities. Partial funding provided by NSF-EAR 1210039, 1329568 and 0447411.

\section{References}

Allison, G.B. and C.J. Barnes. 1983. Estimation of evaporation from non-vegetated surfaces using natural deuterium. Nature. 301:143-145. http://dx.doi.org/10.1038/301143a0

Alpers, C. and G.H. Brimhall. 1988. Middle Miocene climatic change in the Atacama Desert, northern Chile: Evidence from supergene mineralization at La Escondida. Geol. Soc. Am. 
Bull. 100:1640-1656. http://dx.doi.org/10.1130/0016-

7606(1988)100<1640:MMCCIT>2.3.CO;2

Amundson, R.G., O.A. Chadwick, and J.M. Sowers. 1989. A comparison of soil climate and biological activity along an elevation gradient in the eastern Mojave Desert. Oecologia 80:395400. http://dx.doi.org/10.1007/BF00379042

Amundson, R., W. Dietrich, D. Bellugi, S. Ewing, K. Nishiizumi, J. Owen, R. Finkel, A. Heimsath, B. Stewart, and M. Caffee. 2012. Geomorphic evidence for the late Pliocene onset of hyperaridity in the Atacama Desert. Geol. Soc. Amer. Bull. 124:1048-1070. http://dx.doi.org/10.1130/B30445.1

Barnes, C.J. and G.B. Allison. 1988. Tracing of water movement in the unsaturated zone using stable isotopes of hydrogen and oxygen. J. Hydrol. 100:143-176.

http://dx.doi.org/10.1016/0022-1694(88)90184-9

Brimhall, G.H. and W.E. Dietrich. 1987. Constitutive mass balance relations between chemical composition, volume, density, porosity, and strain in metasomatic hydrochemical systems: results on weathering and pedogenesis. Geochim.Cosmochim. Acta. 51:567-587. http://dx.doi.org/10.1016/0016-7037(87)90070-6

Cerling, T.E. 1984. The stable isotopic composition of modern soil carbonate and its relationship to climate. Earth Planet. Sci. Letters. 71:229-240.

http:/ /dx.doi.org/10.1016/0012-821X(84)90089-X

Criss, R.E. 1999. Principles of stable isotope distribution. Oxford Press, NY.

Deines, P., D. Langmuir, and R.S. Harmon 1974. Stable carbon isotope ratios and the existence of a gas phase in the evolution of carbonate ground waters. Geochim. Cosmochim. Acta. 38:1147-1164. http://dx.doi.org/10.1016/0016-7037(74)90010-6

Dunai, T.J., G.A. Gongalez Lopez, and J. Jeuz-Larre. 2005. Oligocene-Miocene age of aridity in the Atacama Desert revealed by dating of erosion sensitive landforms. Geol. 33:321-324. http://dx.doi.org/10.1130/G21184.1

Ewing, S.A., B. Sutter, J. Owen, , K. Nishiizumi, W. Sharp, S.S. Cliff, K. Perry, W.E. Dietrich, C.P. McKay, and R. Amundson. 2006. A threshold in soil formation at Earth's arid-hyperarid transition: Geochimica et Cosmochimica Acta, 70:5293-5322.

http://dx.doi.org/10.1016/j.gca.2006.08.020

Fedoroff, N., M-A. Courty, and Z.G. Guo, 2010. Palaeosoils and relict soils. In: Georges Stoops, Vera Marcelino and Florias Mees, editors, Interpretation of Micromorphological Features of Soils and Regoliths.

Elsevier. 623. ISBN: 978-0-444-53156-8.

Ford, H.L., A.C. Ravelo, P.S. Dekens, J.P. LaRiviere, and M.W. Wara, 2015. The evolution of the equatorial thermocline and the early Pliocene El Padres mean state. Geophys.l Res. Letters 42:4878-4887. 
Gajardo, R., 1994. La Vegetación natural de Chile: clasificación y distribución geográfica. Editorial Universitaria, Santiago.

Garzione, C.N., G.D. Hoke, J.C. Libarkin, S. Withers, B. McFadden, J. Eiler, P. Ghosh, and A. Mulch. 2008. Rise of the Andes. Science 320:1304-1307.

http://dx.doi.org/10.1126/science.1148615

GNIP (Global Network of Isotopes in Precipitation). 2014. International Atomic Energy Agency, Water Resources Program. 22 May 2013. 19 June 2014. http:/ /wwwnaweb.iaea.org/napc/ih/IHS_resources_gnip.html.

Gromet, L.P. and L.T. Silver. 1983. Rare earth element distributions among minerals in a granodiorite and the petrogenetic implications. Geochimica et Cosmochimica Acta. 47:925939. http://dx.doi.org/10.1016/0016-7037(83)90158-8

Hartley, A.J. and G. Chong. 2002. Late Pliocene age for the Atacama Desert: Implications for the desertification of western South America. Geol. 30:43-46.

http://dx.doi.org/10.1130/0091-7613(2002)030<0043:LPAFTA>2.0.CO;2

Harden J. W. 1987. Soils developed in granitic alluvium near Merced, California. U.S. Geol. Surv. Bull. 1590-A.

Houston, J. 2006. Variability of precipitation in the Atacama Desert: Its causes and hydrological impacts. Inter. J.Climatol. 26:2181-2198. http://dx.doi.org/10.1002/joc.1359

Jenny, H. and C.D. Leonard. 1934. Functional relationships between soil properties and rainfall. Soil Sci. 38:363-381. http://dx.doi.org/10.1097/00010694-193411000-00004

Jungers, M.C., A.M. Heimsath, R. Amundson, G. Balco, D. Shuster, and G. Chong. 2013. Active erosion-deposition cycles in the hyperarid Atacama Desert of northern Chile. Earth Planet. Sci. Letters. 371-372:125-133. http://dx.doi.org/10.1016/j.epsl.2013.04.005

Kita, N.T., T. Ushikubo, B. Fu, and J.W. Valley. 2009. High precision SIMS oxygen isotope analyses and the effect of sample topography. Chem.Geol. 264:43-57.

Kozdon, R., T. Ushikubo, N.T. Kita, M. Spicuzza, and J.W. Valley. 2009. Intratest oxygen isotope variability in the planktonic foraminifer $N$. pachyderma: real vs. apparent vital effects by ion microprobe. Chem. Geol. 258:327-337.

Kurtz, A.C., L.A. Derry, and O.A. Chadwick. 2000. Refractory element mobility in volcanic soils. Geology. 28:683-686. http://dx.doi.org/10.1130/0091-

7613(2000)28<683:REMIVS>2.0.CO;2

Moreira-Muñoz, A. 2011. Plant Geography of Chile. Springer.

http://dx.doi.org/10.1007/978-90-481-8748-5 
Mortimer, C. 1973. The Cenozoic history of the southern Atacama Desert, Chile. Geol. Soc.London J. 129:505-526. http://dx.doi.org/10.1144/gsigs.129.5.0505

Moscoso, R., C. Nasi, and P. Salinas. 1982. Hoja Vallenar y parte Norte de La Serena. Serv. Nac. Geol. Miner., Carta Geol. Chile, No. 55.

Oerter, E., R. Amundson, A. Heimsath, M. Jungers, and G. Chong. 2011. Paleosol-based evidence for humid to semi-arid pre-10Ma climates in the Atacama Desert, Chile. American Geophysical Union Annual Meeting, December 5-9. San Francisco, California.

O'Neil, J.R., , R.N. Clayton and T.K. Mayeda. 1969. Oxygen isotope fractionation in divalent metal carbonates. J. Chem. Phys. 51: 5547-5558. NOTE: the equations are recalculated by Freidman and O'Neil (1977) to account for a different value of the $\mathrm{H}_{2} \mathrm{O}-\mathrm{CO}_{2}$ fractionation.

Peters, N.A., K.W. Huntington, and G.D. Hoke. 2012. Hot or not? Impact of seasonally variable soil carbonate formation on paleotemperature and O-isotope records from clumped isotopic thermometry. Earth Planet. Sci. Letters 361:208-218.

http://dx.doi.org/10.1016/j.epsl.2012.10.024

Quade, J., T.E. Cerling, and J.R. Bowman. 1989. Systematic variations in the carbon and oxygen isotopic composition of pedogenic carbonate along elevation transects in the southern Great Basin, United States. Geol. Soc. Am. Bull. 101:464-475. http://dx.doi.org/10.1130/0016-7606(1989)101<0464:SVITCA>2.3.CO;2

Rech, J.A., B.S. Currie, G. Michalski, and A.M. Cowan. 2006. Neogene climate change and uplift in the Atacama Desert, Chile. Geology. 34:761-764.

http://dx.doi.org/10.1130/G22444.1

Retallack, G.J. 2004. Pedogenic carbonate proxies for amount and seasonality of precipitation in paleosols. Geology. 33:333-336. http://dx.doi.org/10.1130/G21263.1

Shurbaji, A-B. M. and F.M. Phillips. 1995. A numerical model for the movement of $\mathrm{H}_{2} \mathrm{O}$, $\mathrm{H}_{2} \mathrm{O}^{18}$, and ${ }^{2} \mathrm{HHO}$ in the unsaturated zone. Journal of Hydrology. 171:125-142.

http://dx.doi.org/10.1016/0022-1694(94)02604-A

Soil Survey Division Staff. 1993. Soil survey manual. Soil Conservation Service. U.S. Department of Agriculture Handbook 18.

Stuut, J-B. and F. Lamy. 2004. Climate variability at the southern boundaries of the Namib (southwestern Africa) and Atacama (northern Chile) coastal deserts during the last 120,000 yr. Quaternary Research. 62:301-309. http://dx.doi.org/10.1016/j.yqres.2004.08.001

Wang, Y., E. McDonald, R. Amundson, L. McFadden, and O. Chadwick. 1996. An isotopic study of soils in chronological sequences of alluvial deposits, Providence Mountains, California. Geol. Soc. Amer. Bull. 108:379-391. http://dx.doi.org/10.1130/00167606(1996)108<0379:AISOSI >2.3.CO;2 
Wara, M.W., A.C. Ravelo, and M.L. DeLaney. 2005. Permanent El Nino-like conditions during the Pliocene warm period. Science. 309:758-761.

http://dx.doi.org/10.1126/science.1112596

White, A.F., M.S. Schulz, D.V. Vivit, A.E. Blum, D.A. Stonestrom, and S.P. Anderson. 2008. Chemical weathering of a marine terrace chronosequence, Santa Cruz, California I:

Interpreting rates and controls based on soil concentration-depth profiles. Geochim.

Cosmochim. Acta. 72:36-68. http://dx.doi.org/10.1016/j.gca.2007.08.029

Table 1. Climate data for the nearest sites to the $\mathrm{N}$ (Copiapo) and S (Vallenar) of the study site. Data from www.climate_charts.com. Annual averages given for temperature and relative humidity $(\mathrm{RH})$, sums for precipitation.

\begin{tabular}{|l|l|l|l|l|l|l|l|l|l|l|l|l|l|l|}
\hline Site & & $\mathbf{J}$ & $\mathbf{F}$ & $\mathbf{M}$ & $\mathbf{A}$ & $\mathbf{M}$ & $\mathbf{J}$ & $\mathbf{J}$ & $\mathbf{A}$ & $\mathbf{S}$ & $\mathbf{O}$ & $\mathbf{N}$ & $\mathbf{D}$ & ave/sum \\
\hline Copiapo & $\mathrm{T}(\mathrm{C})$ & 19.6 & 19.4 & 17.9 & 15.4 & 13.2 & 11.4 & 11.3 & 12.0 & 13.2 & 14.8 & 16.4 & 18.3 & 15.2 \\
\hline $\begin{array}{l}27^{\circ} 18^{\prime} \mathrm{S} \\
70^{\circ} 25^{\prime} \mathrm{W}\end{array}$ & $\begin{array}{l}\mathrm{P} \\
(\mathrm{mm})\end{array}$ & 0 & 0 & 1.1 & 0.2 & 1.4 & 1.1 & 6.5 & 2.0 & 1.2 & 1.5 & 0 & 0 & 12.0 \\
\hline & $\begin{array}{l}\mathrm{RH} \\
(\%)\end{array}$ & 70 & 71 & 75 & 77 & 78 & 78 & 76 & 77 & 75 & 74 & 72 & 70 & 74 \\
\hline Vallenar & $\mathrm{T}(\mathrm{C})$ & 18.6 & 18.6 & 17.1 & 14.9 & 13.1 & 11.7 & 11.4 & 12.2 & 13.0 & 14.5 & 15.6 & 17.5 & 14.9 \\
\hline $\begin{array}{l}28^{\circ} 36^{\prime} \mathrm{S} \\
70^{\circ} 46^{\prime} \mathrm{W}\end{array}$ & $\begin{array}{l}\mathrm{P} \\
(\mathrm{mm})\end{array}$ & 0 & 0 & 0.7 & 1.3 & 4.1 & 3.2 & 11.9 & 7.1 & 2.1 & 1.2 & 0 & 0 & 31.6 \\
\hline & $\begin{array}{l}\mathrm{RH} \\
(\%)\end{array}$ & 68 & 70 & 73 & 74 & 73 & 69 & 69 & 69 & 69 & 69 & 70 & 68 & 70.0 \\
\hline
\end{tabular}




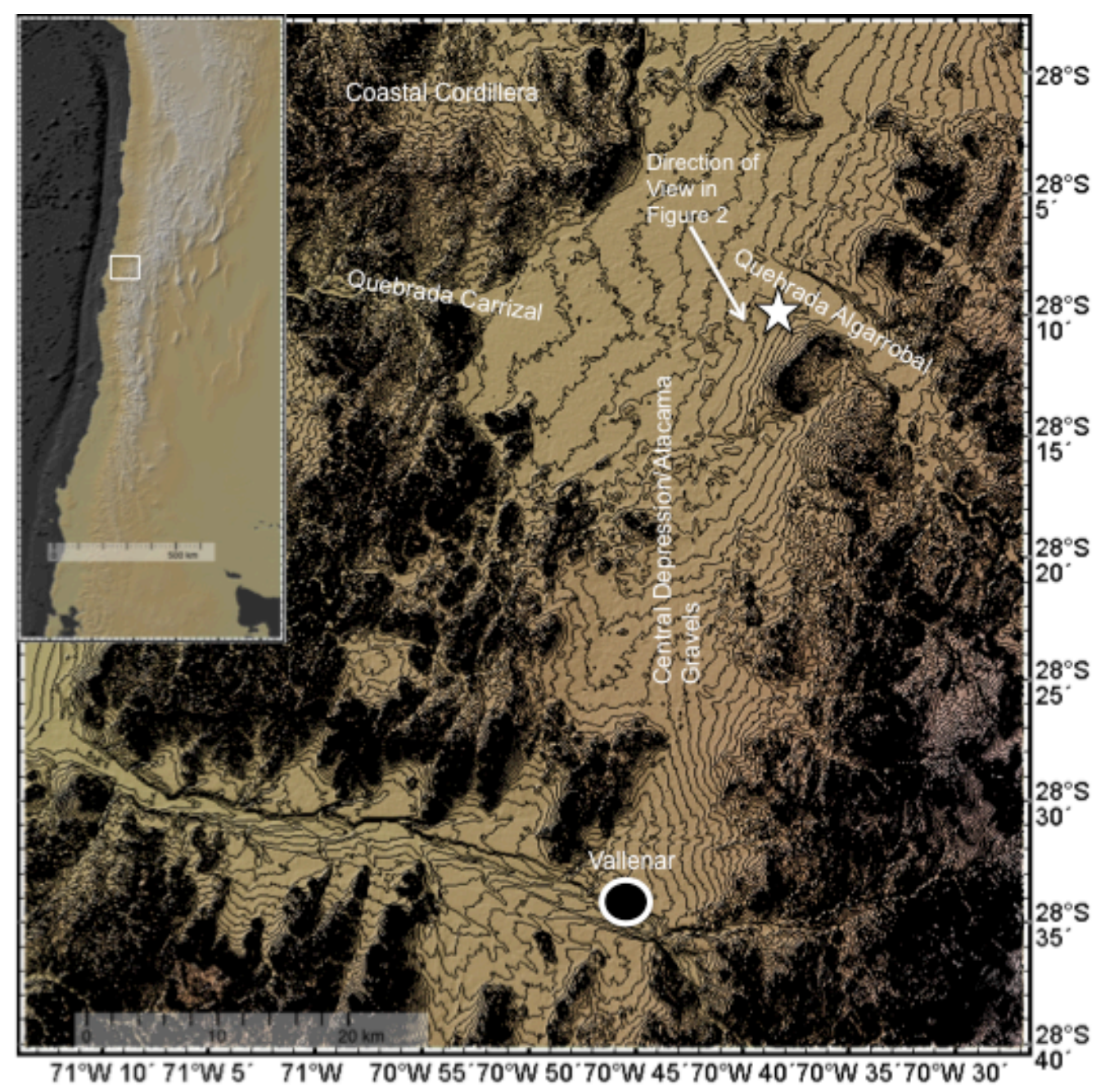

Figure 1. Location of the field area on a DEM of northern Chile (inset) and a $25 \mathrm{~m}$ contour map of the Figure 1. Location of the field area on a DEM of norther
research area (site location is indicated by the white star). 


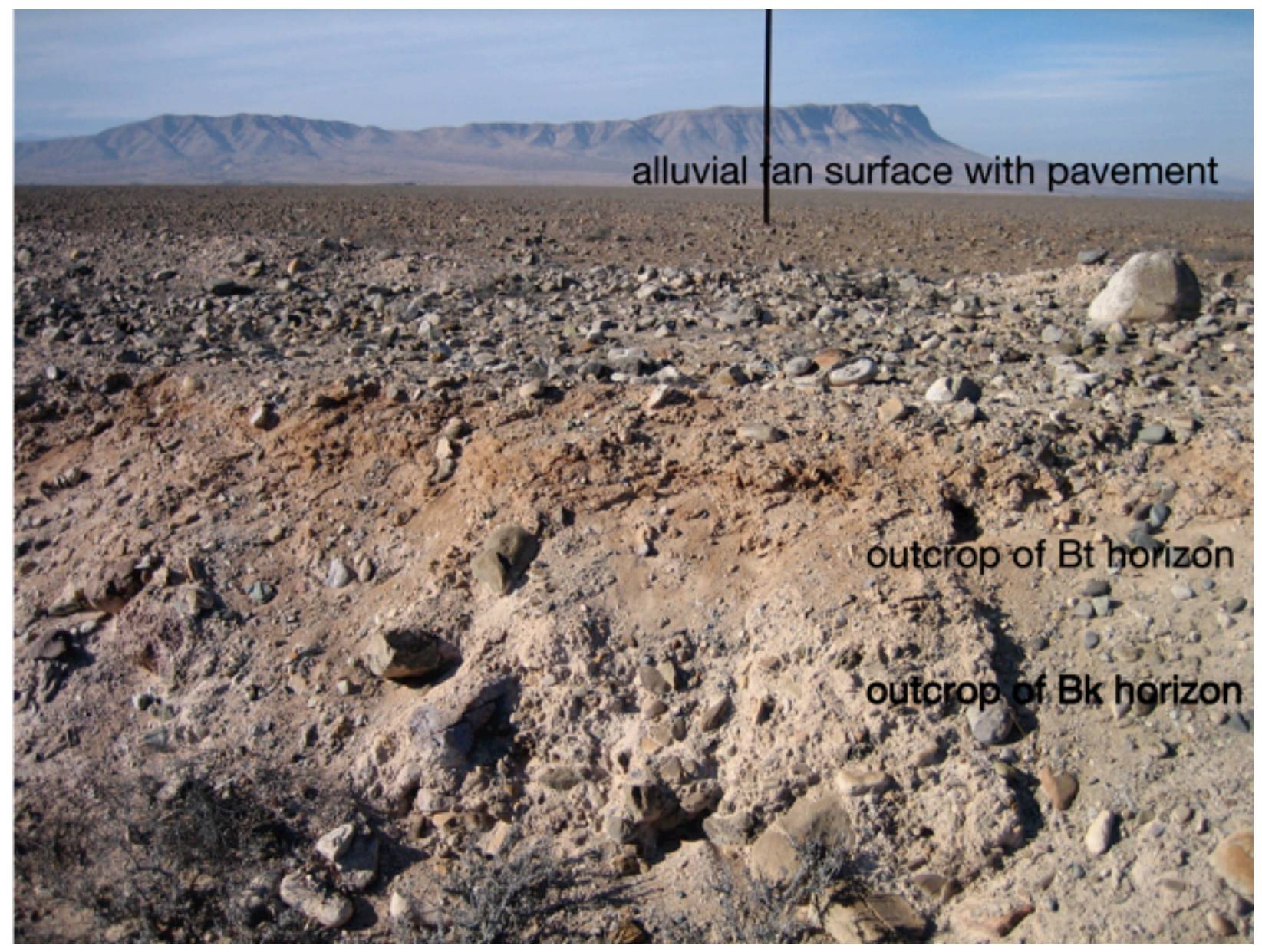

Figure 2. Photograph of the stream escarpment of the Tertiary fan surface that the soil formed into. The fan is nearly level, and covered with a continuous gravelly pavement. Cobbles or gravels in the pavement are commonly highly weathered and fractured. The escarpment (not cleared) shows the reddish colors of the oxidized silicate matrix and a prominent carbonate accumulation. The fan surface has no living plants at the time of study, though some dead (light gray) plants can be seen in the photograph. 
Figure 3. (a) Photograph of the soil (50 $\mathrm{cm}$ pick for reference), with approximate horizon boundaries indicated, and (b) an example of angular blocky clay-rich soil aggregates that have only been partially engulfed by the surrounding carbonate rich material.
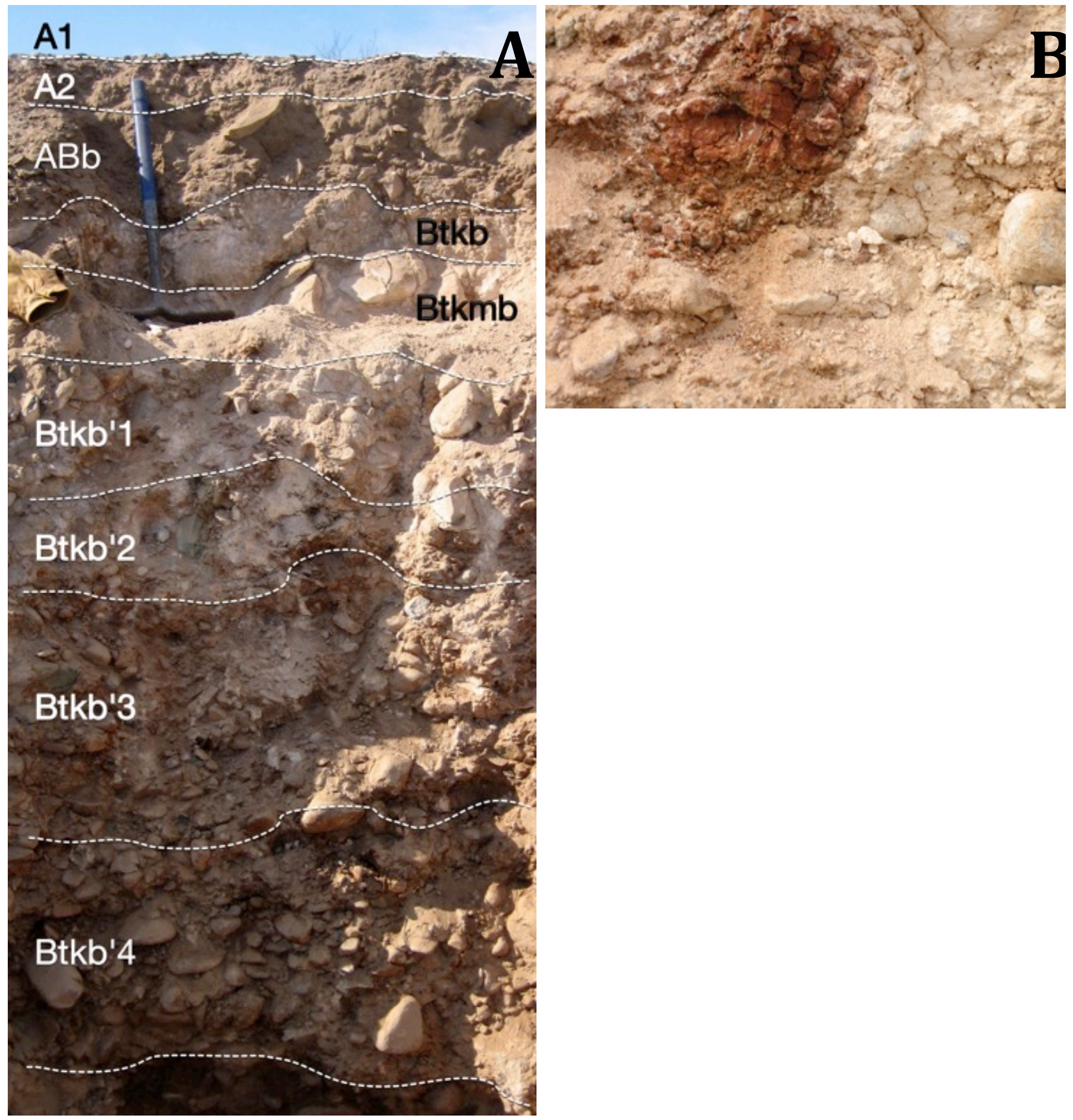


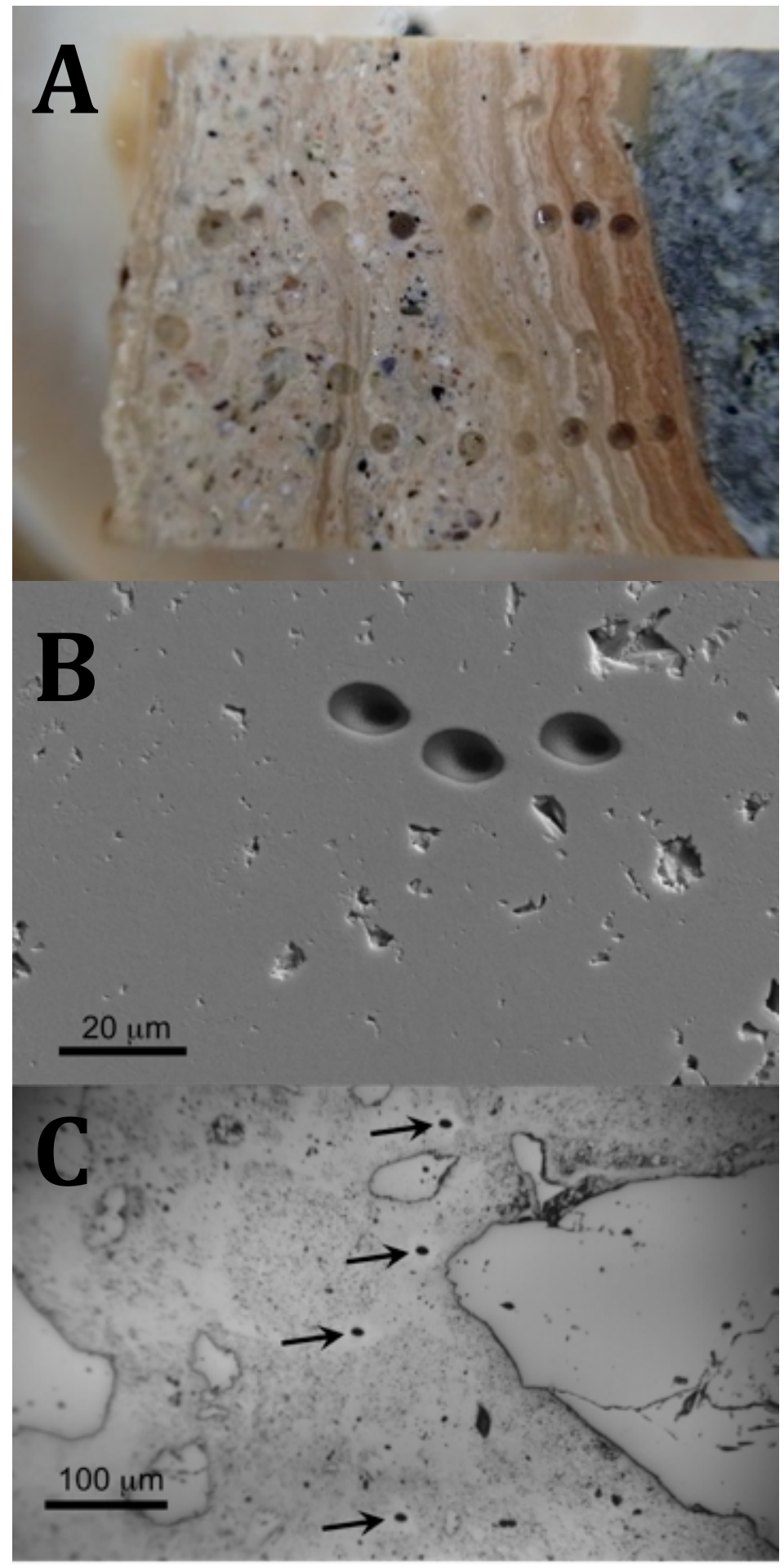

Figure 4. (a) Photograph of carbonate lamination on gravel that has been hand drilled (carbonate $150 \mathrm{~mm}$ ), (b) close-up of 3 nearby ablated SIMS samplings, (c) part of sampling transect, show how samples were made to avoid large detrital grains. 

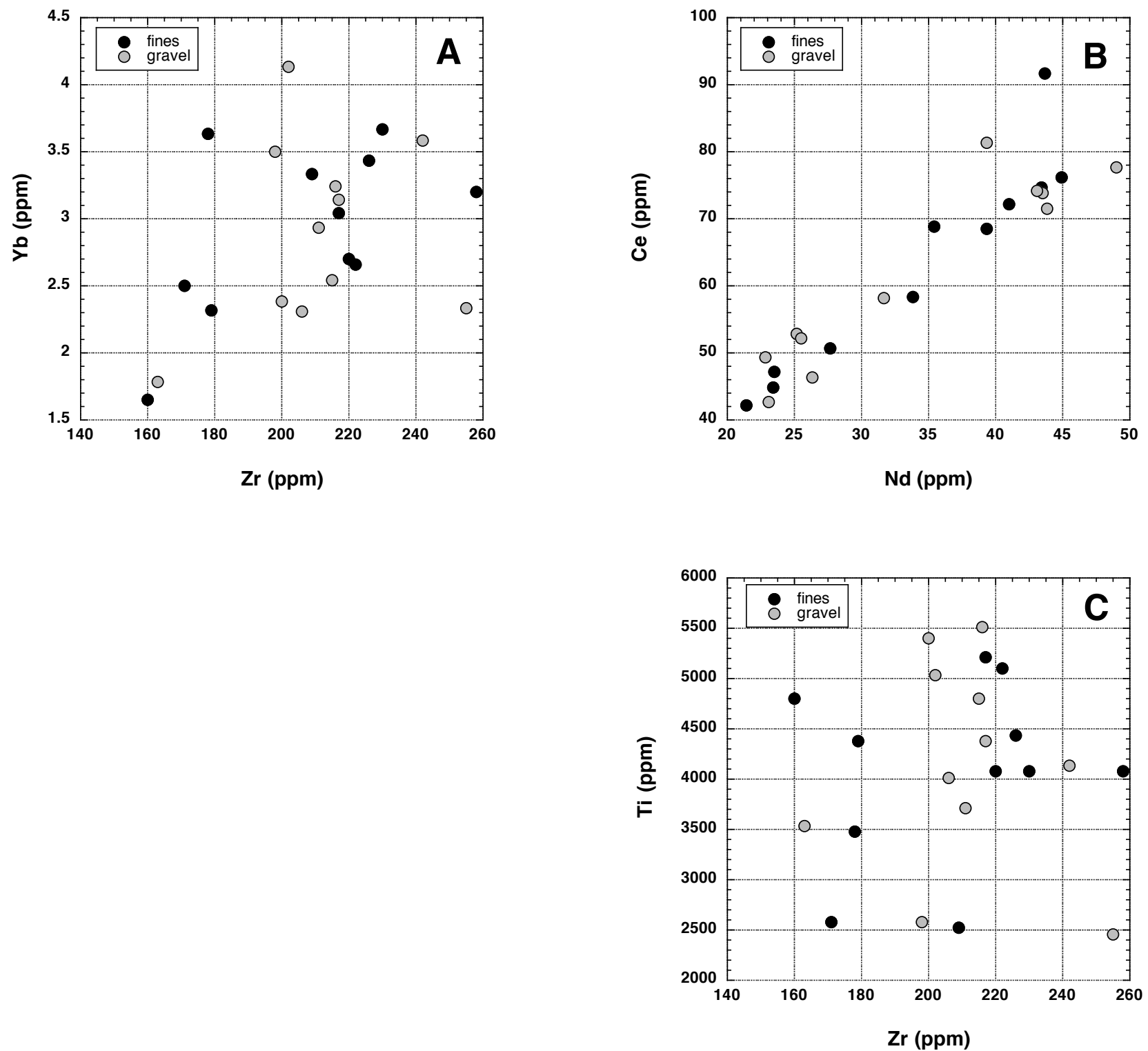

Figure 5. The (a) $\mathrm{Yb}$ vs $\mathrm{Zr}$, (b) Ce vs $\mathrm{Nd}$, and (c) $\mathrm{Ti}$ vs $\mathrm{Zr}$ in the $<2 \mathrm{~mm}$ (fines) and gravel fractions of the soil. 

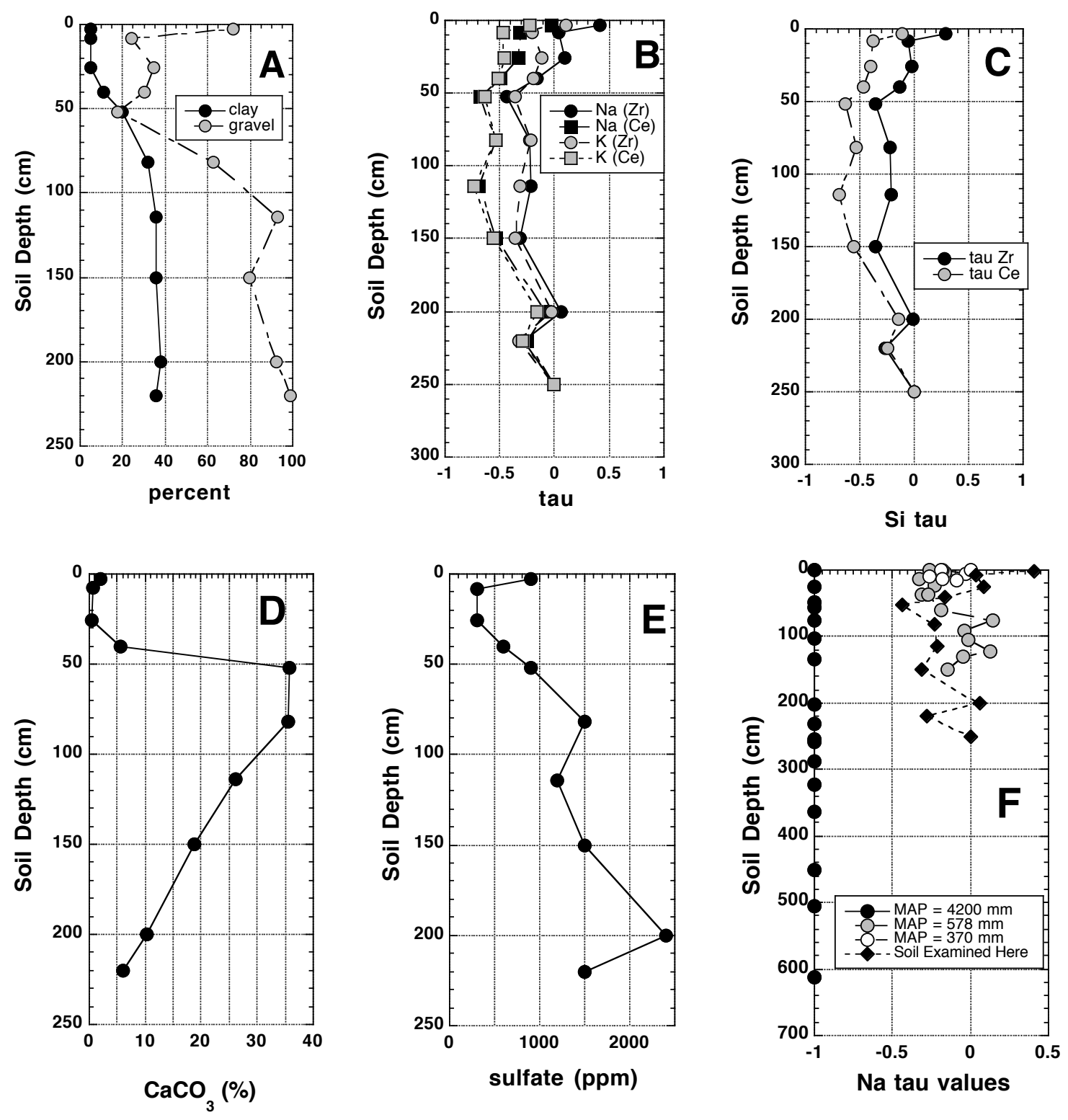

Figure 6. Soil depth (cm) vs. (a) clay and gravel (\% mass), and fractional gains (+) or losses (-) using either $\mathrm{Zr}$ or Ce for (b) $\mathrm{Na}$ and $\mathrm{K}$ and (c) Si. (d) $\mathrm{CaCO}_{3}$ in $<2 \mathrm{~mm}$ fraction, (e) $\mathrm{SO}_{4}$ content of the $<2 \mathrm{~mm}$ fraction, and (f) comparison of soil $\mathrm{Na}$ tau value to sites from different climate regimes (Rasmussen et al., 2011). For tau values, the reference horizon (located at $250 \mathrm{~cm}$ ) is $<2 \mathrm{~mm}$ fraction from fresh sediment. 

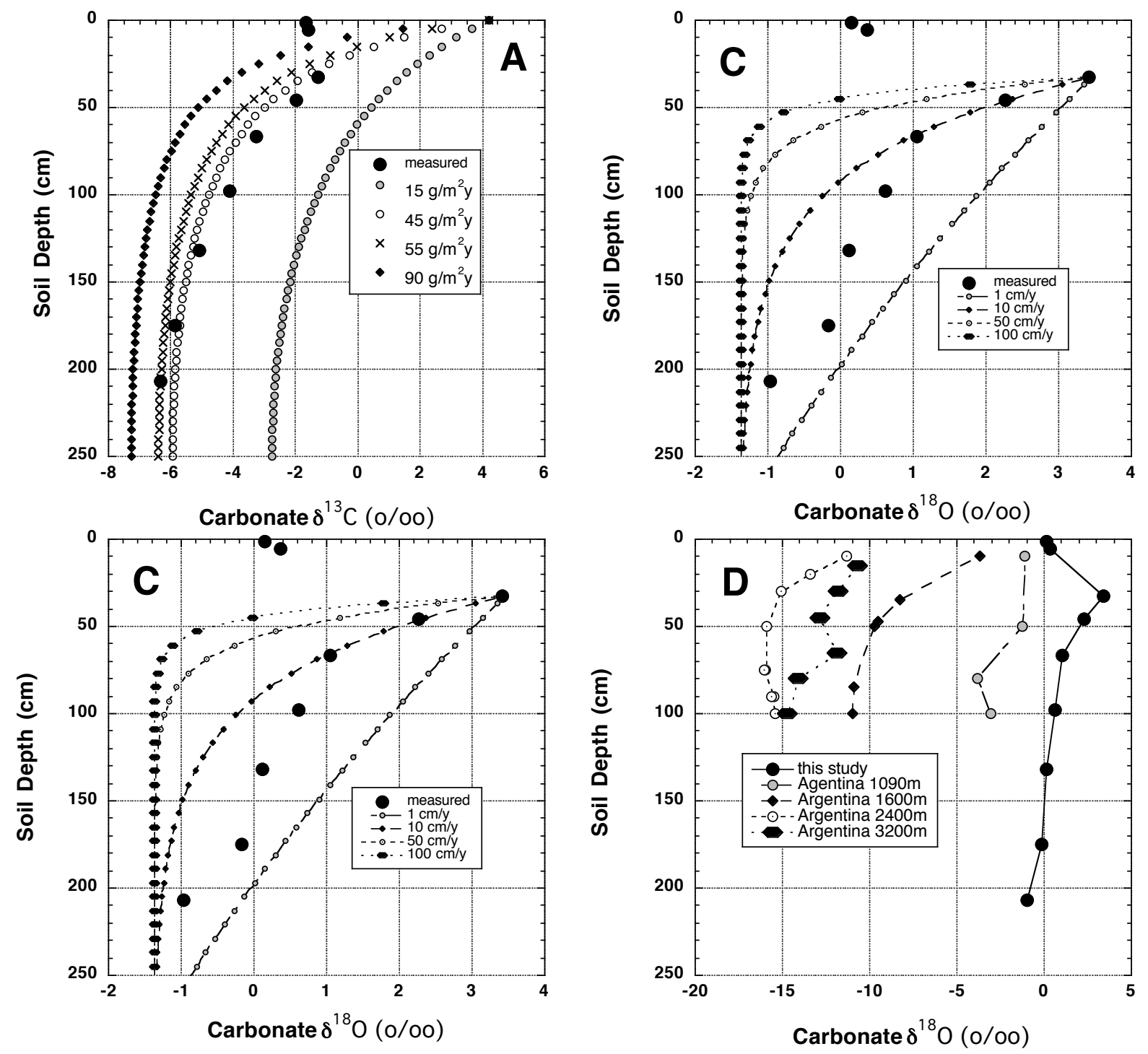

Figure 7. (a) Measured vs. modeled (Eq. 2) C isotope profiles for the soil carbonate in the $<2 \mathrm{~mm}$ fraction, (b) comparison between the $\mathrm{C}$ isotope profile of the studied soil vs. those in more humid settings in Argentina (Peters et al., 2012), (c) measured vs modeled (Eq. 3) O isotope (PDB scale) profile of the $<2 \mathrm{~mm}$ fraction, and (d) comparison between the studied soil and those in Argentina. All isotope values are reported relative to VPDB standard. 

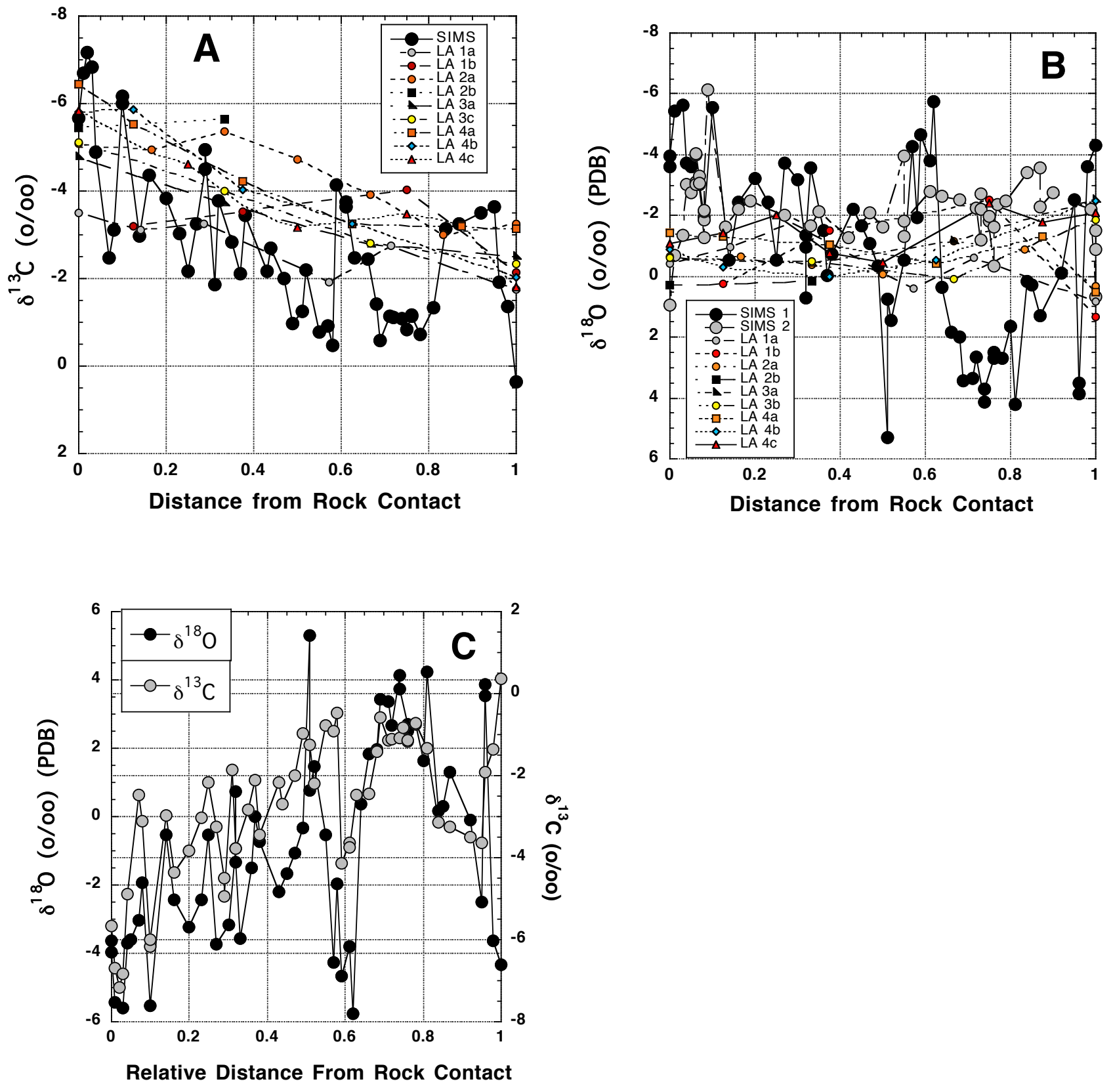

Figure 8. Stable isotope composition of transect along laminated carbonate illustrated in Figure 4, $0=$ rock/carbonate contact and $1=$ edge of laminations, for both hand drilled and SIMS analyses. (a) stable $\mathrm{C}$ isotopes of all samples, (b) stable $\mathrm{O}$ isotopes of all samples, and (c) comparison of $\mathrm{O}$ and $\mathrm{C}$ isotopes from SIM analysis of clast 1. 